\title{
Comparison of the Chemical Compositions of Two Different Non-polar Extracts of Heliotropium sudanicum Aerial Parts from Sudan
}

\author{
Hatil H. El-Kamali ${ }^{1 *}$, Alaa A. Tawfig ${ }^{2}$ and Maha A. Y. Kordofani ${ }^{3}$ \\ ${ }^{1}$ Department of Botany, Faculty of Science and Technology, Omdurman Islamic University, \\ Omdurman, Sudan. \\ ${ }^{2}$ Department of Chemistry, Faculty of Science and Technology, Omdurman Islamic University, \\ Omdurman, Sudan. \\ ${ }^{3}$ Department of Botany, Faculty of Science, University of Khartoum, Sudan.
}

Authors' contributions

This work was carried out in collaboration among all authors. All authors read and approved the final manuscript.

Article Information

DOI: 10.9734/ARRB/2019/v32i530099

Editor(s):

(1) Paola Angelini, Department of Applied Biology, University of Perugia, Perugia, Italy. (2) Dr. Manikant Tripathi, Department of Microbiology, Dr. Ram Manohar Lohia Avadh University, India.

Reviewers:

(1) Shailja Puri, SRL Diagnostics, India. (2) Rupali Sengupta, SNDT Women's University, India. Complete Peer review History: http://www.sdiarticle3.com/review-history/50903

Original Research Article

Received 07 May 2019

Accepted 11 August 2019

Published 20 August 2019

\section{ABSTRACT}

Aim: Heliotropium (Boraginaceae) is a widely spread genus of plants found in the Central and Northern parts in the Sudan and used for the treatment of inflammations, and rheumatism from ancient times. The aim of this work is to provide answers to impending research questions on compounds present in petroleum ether and n-hexane extracts of the aerial parts of $H$. sudanicum. Methodology: Phytochemical analysis of plant extracts was performed by using Gas Chromatography/Mass Spectrometer. Various constituents were identified after matching their mass fragmentation pattern with data available in Gas Chromatography/Mass Spectrometer library of National Institute of Standards Technology (NIST).

Results: Petroleum ether extract of $H$. sudanicum was characterized by abundance of 1,6,10,14,18,22- Tetracosahexaen-3-ol, 2,6,10,15,19,23-hexamethyl-, (all-E)- (33.99\%), Squalene $(20.94 \%)$, Phytol $(7.62 \%)$ and Hexatriacontane $(7.49 \%)$. The constituents of the extract were fatty 
acid derivatives (15.24\%), hydrocarbons (8.41\%) and terpenoids (28.56\%). H. sudanicum n-hexane extract was characterized by abundance of 9,12-Octadecadienoic acid (Z,Z)-,methyl ester (15.14\%), 9,12,15-Octadecatrienoic acid, methyl ester (14.67\%), Cholesterol (11.12\%), Fucosterol (10.30\%), gamma.-Sitosterol (9.59\%) and1,6,10,14,18,22- Tetracosahexaen-3-ol, 2,6,10,15,19,23hexamethyl-, (all-E)- (7.73\%).

Conclusion: The resulted compounds in this study provide evidence for the utilization of the plant as alternative natural resource of medicinal and industrial interest. To best of our knowledge this is the first report that directly compares the two extraction solvents for active compounds from Heliotropium sudanicum aerial parts shows that petroleum ether should be the solvent of choice.

Keywords: Heliotropium sudanicum; Boraginaceae; aerial parts; chemical composition; non-polar solvents; Sudan.

\section{INTRODUCTION}

The genus Heliotropium L. (Boraginaceae) with about 300 species all over the world. Is a genus of herbs rarely shrubs. It is used in folk medicine for the treatment of gout, rheumatism and as antiseptic and inflammatory agent. In Sudan, the whole herb is used for animal wound healing $[1,2,3]$. It is one of the main sources of pyrrolizidine alkaloids (PAs). PAs - containing plants have been recognized responsible for poisoning of livestock and other ruminants [1,46]. H. sudanicum aerial parts was found by ALHassan et al.; [2] contains alkaloids, coumarins, flavonoids, tannins and steroids/triterpenes.

The $H$. sudanicum F.W.Andr. plant is a branched annual herb. Stems sulcate, hispid. Leaves alternate, petiolate. sinuate, often of unequal base, $5 \mathrm{~cm}$. long. Spikees often in pairs. Corolla white, twice as long as calyx, pubescent outside Stigma conical, thickened at base. Nutlets glabrous [7]. In the stem transverse section . the anatomical structure of stem ${ }^{6}$ were shows that the upper epidermis is a single layer of barrelshaped dense cytoplasm with conspicuous nuclei, it is found as one layer. The presence of hairs and other epidermal outgrowths have been noted. The hypodermis consist of 2-3 layers of collenchymatous cells. The cells of general cortex consist of parenchymatous cells in 4 layers. While in the leaf transverse section, the anatomical structure of leaf $^{7}$ shows that the epidermal cells are rectangular and show the presence of an external cuticular layer. The upper epidermal cells are somewhat larger than the lower. Unicellular epiderma; trichomes have been noted on both surfaces. Stomata is of anomocytic type and are distributed on the upper and lower epidermis of the leaves. Palisade layers range from 2 to 4 . The main vascular bundle is 1 the lateral vascular bundle are 4 [8].
The aim of the research is to compare chemical analysis of petroleum ether and n-hexane extracts from $H$. sudanicum aerial parts through gas chromatography /mass spectrometer (GC/MS).

\section{MATERIALS AND METHODS}

\subsection{Plant Materials}

Aerial parts from Heliotropium sudanicum were collected in April 2017 from Shambat area (Khartoum State, Central Sudan). The studied species was taxonomically identified by Prof. M. Kordofani (Department of Botany, Khartoum University) and Ustaz. H. Tag EL-Sir (Department of Agricultural Botany, Khartoum University).

\subsection{Sample Preparation}

Each plant sample was carefully dried in the shade at room temperature. The aerial parts were then ground to fine powder with a mechanical crusher and the powder was kept in glass container at room temperature.

\subsection{Extraction}

Petroleum ether and n-hexane were used as solvents of extraction. The powder was extracted separately with $250 \mathrm{ml}$ petroleum ether and n-hexane at room temperature for 24 hours. After extraction it was filtered and then the removal of solvent was done by distillation device. Then the $(70 \mathrm{ml})$ extract was kept in glass container.

\subsection{Gas Chromatography Mass Spectrometer (GC/MS)}

GC was equipped with MS (Shimatzo QP 2010 GC/MS instrument equipped with reference 
libraries). Packed material for column were $50 \%$ phenyl and $50 \%$ methyl polysiloscane, column length 30 meter, diameter $0.025 \mathrm{~mm}$, the flow rate of helium as carrying gas was $1 \mathrm{ml} / \mathrm{min}$.the temperature of program consisted of 60-270 C , at rate of $4 \mathrm{C} / \mathrm{min}$. MS were taken at ionization voltage $70 \mathrm{EV}$. Library search was carried out using Wiley GC/MS library.

\subsubsection{Identification of components}

Interpretation on mass spectrum GC-MS was conducted using the database of National Institute Standard and Technology (NIST). The spectrum of the unknown component was compared with the spectrum of the known components stored in the NIST library. The name, formula, molecular weight and area $\%$ of the components of the test materials were ascertained.

\section{RESULTS AND DISCUSSION}

\subsection{GC/MS Analysis of $H$. sudanicum Petroleum Ether Extract}

A total of 15 compounds representing $100 \%$ of the Petroleum Ether extract were identified and is given in the Table 1. Quantitatively, the extract was characterized by abundance of 1,6,10, 14,18,22- Tetracosahexaen-3-ol, 2,6,10,15,19, 23-hexamethyl-, (all-E)- (33.99\%) , Squalene $(20.94 \%)$, Phytol $(7.62 \%)$ and Hexatriacontane $(7.49 \%)$.

The identified compounds comprised many secondary metabolites as hydrocarbons, terpenes, phytosterol, Phenolic compounds and the majority is the fatty acids derivatives. The major component was identified as a 1,6,10,14,18,22-Tetracosahexaen-3-ol, 2,6,10, 15,19,23-hexamethyl-, (all-E)-(33.99\%). Many methyl esters of fatty acids are identified including Hexadecanoic acid,methyl ester, 9,12,15-Octadecatrienoic acid, methyl ester, 9Octadecenoic acid (Z)-, methyl ester, Methyl stearate.

The fatty acid methyl ester 9-Octadecenoic acid (Z)-,methyl ester (5.42\%) known also as Methyl oleate is used in Industry as Intermediates, lubricants and lubricant additives, Solvents (which become part of product formulation or mixture). and the consumer use it in ink, toner, colorant products lubricants, greases and water treatment products [9].
Many hydrocarbons are identified such as Heneicosane, Hexatriacontane and they are acyclic alkanes (aliphatic hydrocarbon). The detected Phenolic compound was Phenol, 2,4bis(1,1-dimethylethyl)- $(0.16 \%)$ it is very toxic to aquatic organisms, and uses as a chemical intermediate for the synthesis of UV stabilizers or antioxidants and a chemical intermediate for the synthesis of other chemical intermediates [10]. And also the triterpenoid, Squalene was detected.

The constituents of the extract were fatty acid derivatives $(15.24 \%)$, hydrocarbons $(8.41 \%)$ and terpenoids $(28.56 \%)$.

\subsection{GC/MS Analysis of $\boldsymbol{H}$. sudanicum n- hexane Extract}

A total of 20 compounds representing $100 \%$ of the Petroleum Ether extract were identified and is given in the Table 2. Quantitatively, the extract was characterized by abundance of 9,12-Octadecadienoic acid (Z,Z)-, methyl ester (15.14\%), 9,12,15-Octadecatrienoic acid, methyl ester $(14.67 \%)$, Cholesterol $(11.12 \%)$, Fucosterol (10.30\%), gamma.-Sitosterol (9.59\%), 1,6,10,14,18,22- Tetracosahexaen-3-ol, 2,6,10,15,19,23-hexamethyl-, (all-E)- (7.73\%), .beta. - Sitosterol $(6.66 \%)$ and Hexadecanoic acid, methyl ester (5.05\%).

The constituents of the extract were fatty acid derivatives $(42.04 \%)$, phytosterols $(37.67 \%)$ and terpenoids $(5.52 \%)$. The identified compounds comprised many secondary metabolites as hydrocarbons, terpenes, phytosterol, vitamin and the majority is the fatty acids and their derivatives. The major component was identified as 9,12-Octadecadienoic acid $(Z, Z)-$, methyl ester $(15.14 \%)$ the second major component is $9,12,15-O c t a d e c a t r i e n o i c ~ a c i d$, methyl ester and they are fatty acid methyl ester.

The identified methyl esters of fatty acids are the same as that detected in the petroleum ether extract beside three different methyl esters, they are Methyl tetradecanoate, Eicosanoic acid, methyl ester, and Docosanoic acid, methyl ester.

Many phytosterols (plant sterols) were detected and they are gamma.-Sitosterol, beta.Sitosterol, Cholesterol, Fucosterol. beta.Sitosterol and these may have the potential for prevention and therapy for human cancer, used to make medicine, used for heart disease and high cholesterol and the common cold and flu 
(influenza). Cholesterol it is the major precursor for the synthesis of vitamin $D$ of the various steroid hormones. One vitamin was detected it is Vitamin E (alpha tocopherol), and it's has antioxidant activity, It may also have antiatherogenic, antithrombotic, anticoagulant, neuroprotective, antiviral, immunomodulatory, cell membrane-stabilizing and antiproliferative actions.

Non-polar extracts are rich with fats, steroids and fixed oil. Steroids are type of medicine with strong anti-inflammatory effects. They help to reduce redness, swellings and soreness. Fatty acids have many functions in the body, they play a role in oxygen transport through the body providing energy. The essential fatty acids can carry fat-soluble vitamins $(A, D, E$ and $K$ ) which help body to absorb most of its nutrients $[11,12]$. Phytochemical reports on genus Heliotropium revealed the presence of many bioactive components especially pyrrolizidine alkalois, terpenoids and flavonoids . H. sudanicum aerial parts was found by AL-Hassan et al. [2] contains alkaloids, coumarins, flavonoids, tannins and steroids/triterpenes.

Table 1. Chemical compounds from $H$. sudanicum petroleum ether extract

\begin{tabular}{|c|c|c|c|c|c|c|}
\hline $\begin{array}{l}\text { Sr. } \\
\text { no. }\end{array}$ & R. time & $\begin{array}{l}\text { Name of the } \\
\text { compound }\end{array}$ & Other name & $\begin{array}{l}\text { Molecular } \\
\text { formula }\end{array}$ & $\begin{array}{l}\text { Molecular } \\
\text { weight }\end{array}$ & Area \% \\
\hline 1 & 3.184 & Hexane,2-nitro & - & $\mathrm{C}_{6} \mathrm{H}_{13} \mathrm{NO}_{2}$ & 131.1729 & 3.81 \\
\hline 2 & 11.194 & $\begin{array}{l}\text { Phenol, 2,4-bis(1,1- } \\
\text { dimethylethyl)- }\end{array}$ & $\begin{array}{l}\text { 2,4-di-tert- } \\
\text { butylphenol }\end{array}$ & $\mathrm{C}_{14} \mathrm{H}_{22} \mathrm{O}$ & 206.33 & 0.16 \\
\hline 3 & 14.865 & $\begin{array}{l}\text { 2-pentadecanone, } \\
\text { 6,10,14-trimethyl- }\end{array}$ & $\begin{array}{l}\text { Perhydrofarnesyl } \\
\text { acetone }\end{array}$ & $\mathrm{C}_{18} \mathrm{H}_{36} \mathrm{O}$ & 268.4778 & 2.08 \\
\hline 4 & 14.902 & $\begin{array}{l}\text { 1- } \\
\text { Hexadecanol,3,7,11,15- } \\
\text { tetramethyl- }\end{array}$ & Dihydrophytol & $\mathrm{C}_{20} \mathrm{H} 42 \mathrm{O}$ & 298.5469 & 1.72 \\
\hline 5 & 15.672 & $\begin{array}{l}\text { Hexadecanoic } \\
\text { acid,methyl ester }\end{array}$ & Methyl palmitate & $\mathrm{C}_{17} \mathrm{H}_{34} \mathrm{O}_{2}$ & 270.4507 & 2.69 \\
\hline 6 & 17.324 & $\begin{array}{l}\text { 9-Octadecenoic acid } \\
\text { (Z)-,methyl ester }\end{array}$ & oleic acid ester & $\mathrm{C}_{19} \mathrm{H}_{36} \mathrm{O}_{2}$ & 296.4879 & 5.42 \\
\hline 7 & 17.380 & $\begin{array}{l}\text { 9-Octadecenoic acid } \\
\text { (Z)-,methyl ester }\end{array}$ & oleic acid ester & $\mathrm{C}_{19} \mathrm{H}_{36} \mathrm{O}_{2}$ & 296.4879 & 1.87 \\
\hline 8 & 17.394 & $\begin{array}{l}9,12,15- \\
\text { Octadecatrienoic acid, } \\
\text { methyl ester }\end{array}$ & $\begin{array}{l}\text { methyl octadeca- } \\
9,12,15 \text {-trienoate }\end{array}$ & $\mathrm{C}_{19} \mathrm{H}_{32} \mathrm{O}_{2}$ & 292.4562 & 4.45 \\
\hline 9 & 17.493 & Phytol & $\begin{array}{l}3,7,11,15- \\
\text { Tetramethyl-2- } \\
\text { hexadecen-1-ol }\end{array}$ & $\mathrm{C}_{20} \mathrm{H}_{40} \mathrm{O}$ & 296.5310 & 7.62 \\
\hline 10 & 19.072 & Methyl stearate & $\begin{array}{l}\text { methyl } \\
\text { octadecanoate }\end{array}$ & $\mathrm{C}_{19} \mathrm{H}_{38} \mathrm{O}_{2}$ & 298.511 & 0.81 \\
\hline 11 & 19.072 & Heneicosane & - & $\mathrm{C}_{21} \mathrm{H}_{44}$ & 296.583 & 0.92 \\
\hline 12 & 20.684 & $\begin{array}{l}\text { Tetratriacontyl } \\
\text { heptafluorobutyrate }\end{array}$ & - & $\mathrm{C}_{38} \mathrm{H}_{69} \mathrm{~F}_{7} \mathrm{O}_{2}$ & 690.9421 & 5.95 \\
\hline 13 & 23.207 & Squalene & - & $\mathrm{C}_{30} \mathrm{H}_{50}$ & 410.73 & 20.94 \\
\hline 14 & 23.612 & Hexatriacontane & - & $\mathrm{C}_{36} \mathrm{H}_{74}$ & 506.988 & 7.49 \\
\hline \multirow[t]{2}{*}{15} & 23.953 & $\begin{array}{l}1,6,10,14,18,22- \\
\text { Tetracosahexaen-3-ol, } \\
2,6,10,15,19,23- \\
\text { hexamethyl-, (all-E)- }\end{array}$ & $\begin{array}{l}(6 \mathrm{E}, 10 \mathrm{E}, 14 \mathrm{E}, \\
18 \mathrm{E})- \\
2,6,10,15,19,23- \\
\text { hexamethyltetrac } \\
\text { osa- } \\
1,6,10,14,18,22- \\
\text { hexaen-3-ol }\end{array}$ & $\mathrm{C}_{30} \mathrm{H}_{50} \mathrm{O}$ & 426.729 & 33.99 \\
\hline & & & & & & 100.0 \\
\hline
\end{tabular}


Table 2. Chemical compounds from H.sudanicum $\mathrm{n}$-hexane extract

\begin{tabular}{|c|c|c|c|c|c|c|}
\hline $\begin{array}{l}\text { Sr. } \\
\text { no. }\end{array}$ & R. time & $\begin{array}{l}\text { Name of the } \\
\text { compound }\end{array}$ & Other name & $\begin{array}{l}\text { Molecular } \\
\text { formula }\end{array}$ & MW & Area \% \\
\hline 1 & 13.571 & Methyl tetradecanoate & Methyl myristate & $\mathrm{C}_{15} \mathrm{H}_{30} \mathrm{O}_{2}$ & 242.403 & 0.22 \\
\hline 2 & 14.864 & $\begin{array}{l}\text { 2-pentadecanone, } \\
6,10,14 \text {-trimethyl- }\end{array}$ & $\begin{array}{l}\text { Perhydrofarnesyl } \\
\text { acetone }\end{array}$ & $\mathrm{C}_{18} \mathrm{H}_{36} \mathrm{O}$ & 268.4778 & 0.47 \\
\hline 3 & 14.900 & $\begin{array}{l}6,10,14-\text { Trimethyl- } \\
\text { pentadecan-2-ol }\end{array}$ & - & $\mathrm{C}_{18} \mathrm{H}_{38} \mathrm{O}$ & 270.501 & 0.33 \\
\hline 4 & 15.671 & $\begin{array}{l}\text { Hexadecanoic } \\
\text { acid,methyl ester }\end{array}$ & Methyl palmitate & $\mathrm{C}_{17} \mathrm{H}_{34} \mathrm{O}_{2}$ & 270.4507 & 5.05 \\
\hline 5 & 17.325 & $\begin{array}{l}\text { 9,12-Octadecadienoic } \\
\text { acid (Z,Z)-, methyl } \\
\text { ester }\end{array}$ & Methyl linolate & $\mathrm{C}_{19} \mathrm{H}_{34} \mathrm{O}_{2}$ & 294.4721 & 15.14 \\
\hline 6 & 17.380 & $\begin{array}{l}\text { 9-Octadecenoic acid } \\
\text { (Z)-,methyl ester }\end{array}$ & oleic acid ester & $\mathrm{C}_{19} \mathrm{H}_{36} \mathrm{O}_{2}$ & 296.4879 & 4.04 \\
\hline 7 & 17.397 & $\begin{array}{l}9,12,15- \\
\text { Octadecatrienoic acid, } \\
\text { methyl ester }\end{array}$ & $\begin{array}{l}\text { methyl octadeca- } \\
9,12,15 \text {-trienoate }\end{array}$ & $\mathrm{C}_{19} \mathrm{H}_{32} \mathrm{O}_{2}$ & 292.4562 & 14.67 \\
\hline 8 & 17.491 & Phytol & $\begin{array}{l}3,7,11,15- \\
\text { Tetramethyl-2- } \\
\text { hexadecen-1-ol }\end{array}$ & $\mathrm{C}_{20} \mathrm{H}_{40} \mathrm{O}$ & 296.5310 & 1.20 \\
\hline 9 & 17.584 & Methyl stearate & $\begin{array}{l}\text { methyl } \\
\text { octadecanoate }\end{array}$ & $\mathrm{C}_{19} \mathrm{H}_{38} \mathrm{O}_{2}$ & 298.511 & 2.04 \\
\hline 10 & 18.731 & gamma.-Sitosterol & Clionasterol & $\mathrm{C}_{29} \mathrm{H}_{50} \mathrm{O}$ & 414.7067 & 9.59 \\
\hline 11 & 18.886 & .beta.- Sitosterol & - & $\mathrm{C}_{29} \mathrm{H}_{50} \mathrm{O}$ & 414.7067 & 6.66 \\
\hline 12 & 19.003 & Cholesterol & - & $\mathrm{C}_{27} \mathrm{H}_{46} \mathrm{O}$ & 386.664 & 11.12 \\
\hline 13 & 19.341 & $\begin{array}{l}\text { Eicosanoic acid,methyl } \\
\text { ester }\end{array}$ & Methyl eicosanoate & $\mathrm{C}_{21} \mathrm{H}_{42} \mathrm{O}_{2}$ & 326.5570 & 0,45 \\
\hline 14 & 19.939 & Fucosterol & - & $\mathrm{C}_{29} \mathrm{H}_{48} \mathrm{O}$ & 412.702 & 10.30 \\
\hline 15 & 20.963 & $\begin{array}{l}\text { Docosanoic } \\
\text { acid,methyl ester }\end{array}$ & Methyl Behenate & $\mathrm{C}_{23} \mathrm{H}_{46} \mathrm{O}_{2}$ & 354.6101 & 0.88 \\
\hline 16 & 21.087 & $\begin{array}{l}\text { Stigmast-5-en-3- } \\
\text { ol,oleate }\end{array}$ & & $\mathrm{C}_{47} \mathrm{H}_{82} \mathrm{O}_{2}$ & 679.171 & 1.98 \\
\hline 17 & 21.764 & Vitamin E & alpha tocopherol & $\mathrm{C}_{29} \mathrm{H}_{50} \mathrm{O}_{2}$ & 430.717 & 2.51 \\
\hline 18 & 23.202 & Squalene & - & $\mathrm{C}_{30} \mathrm{H}_{50}$ & 410.73 & 4.36 \\
\hline 19 & 23.607 & Hexatriacontane & - & $\mathrm{C}_{36} \mathrm{H}_{74}$ & 506.988 & 1.27 \\
\hline 20 & 23.949 & $\begin{array}{l}\text { 1,6,10,14,18,22- } \\
\text { Tetracosahexaen-3-ol, } \\
2,6,10,15,19,23- \\
\text { hexamethyl-, (all-E)- }\end{array}$ & $\begin{array}{l}(6 \mathrm{E}, 10 \mathrm{E}, 14 \mathrm{E}, 18 \mathrm{E})- \\
2,6,10,15,19,23- \\
\text { hexamethyltetracosa- } \\
1,6,10,14,18,22- \\
\text { hexaen-3-ol }\end{array}$ & $\mathrm{C}_{30} \mathrm{H}_{50} \mathrm{O}$ & 426.729 & 7.73 \\
\hline
\end{tabular}

\section{CONCLUSION}

To best of our knowledge this is the first report that directly compares the two extraction solvents for active compounds from Heliotropium sudanicum aerial parts shows that petroleum ether should be the solvent of choice. GC-MS analysis result of large Quantities of 1,6,10,14,18,22-tetracosahexaen-3 ol,2,6,15,19, 23-hexamethyl-,(all-E), squalene, phytol and hexatriacontane were extracted by petroleum ether and weren't extracted by n-hexane. 9,12,15-octacatrienoic acid,methyl ester and hexadecanoic acid, methyl ester were found in nhexane extract in a large quantity compared by the extraction quantity in petroleum ether extract.

\section{ACKNOWLEDGEMENT}

The authors would like to thank Scientific Research Authority, Ministry of Higher Education and Scientific Research, Sudan for full financial support. 


\section{COMPETING INTERESTS}

Authors have declared that no competing interests exist.

\section{REFERENCES}

1. Goyal N, Sharma SK. Bioactive phytoconstituents and plant extracts from genus Heliotropium. Int J. Green Pharm. 2014;8(4):217-225.

2. AL-Hassan MS, Koko WS, Khalid HS. Evaluation of antimicrobial, antioxidant and phytochemical screening of some Sudanese medicinal plants. International Journal of Multidisciplinary Research and Development. 2018;5(3):35-39.

3. Abdalla WE, Abdalla EM. Promising sudanese medicinal plants with antibacterial acitivity - A review article. Biological Forum - An International Journal. 2016;8(1):299-323.

4. El-Shazly A, Wink M. Diversity of pyrrolizidine alkaloids in Boraginaceae structures, distribution and biological properties. Diversity. 2014;6(2):188-282.

5. Fu PP, Xia Q, Lin G, Chou MW. Genotoxic pyrrolizidine alkaloids-mechanisms leading to DNA adduct formation and tumorigenicity. Int J Mol Sci. 2002;3(9): 948-964.

6. Wiedenfeld $\mathrm{H}$, Edgar J. Toxicity of pyrrolizidine alkaloidsto humans and ruminants. Phytochem Rev. 2011;10(1): 137-151.

7. Tawfig AA. Comparison of the chemical constituents of two species of Heliotropium (Family: Boraginaceae) from Sudan. M.Sc. Thesis. Omdurman Islamic University; 2018.

8. Ahmed HO, Kordofani MA. Leaf and stem anatomy of five species from the genus Heliotropium L. (Boraginaceae) in Sudan. Journal of Chemical and Pharmaceutical Research. 2012;4(10):4575-4581.

9. Available:https://pubchem.ncbi.nim.nih.gov /compound/9-Octadecanoic acid (Z),methyl ester/

10. Available:https://pubchem.ncbi.nim.nih.gov /compound/Phenol 2,4-bis(1,1dimethylethyl)-/

11. Available:https://www.healthline.com

12. Ajiwe VIE, Okeke CA, Agbo HU. Extraction and utilization of breadfruit seed oil (Treculia africana), Biosources Technology. 1995;53:183-184.

(c) 2019 El-Kamali et al.; This is an Open Access article distributed under the terms of the Creative Commons Attribution License (http://creativecommons.org/licenses/by/4.0), which permits unrestricted use, distribution, and reproduction in any medium, provided the original work is properly cited.

Peer-review history:

The peer review history for this paper can be accessed here: http://www.sdiarticle3.com/review-history/50903 